\title{
BURIAL PRACTICES DURING THE LATE FORMATIVE/EARLY CLASSIC IN THE BANDERAS VALLEY AREA OF COASTAL WEST MEXICO
}

Made available courtesy of Cambridge University Press: http://dx.doi.org/10.1017/S0956536106060184

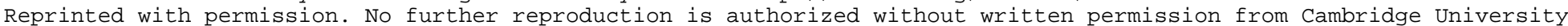
Press

Joseph B. Mountjoy and Mary K. Sandford

Anthropology Department, The University of North Carolina at Greensboro, P.O. Box 26170, Greensboro, NC 27402-6170

\begin{abstract}
In this article we report on the results of our attempts to locate and study shaft-and-chamber tombs in the Municipality of Puerto Vallarta on the southern (Jalisco) side of the Banderas Valley of coastal West Mexico and to place these tombs in the broader context of burial practices in this area during a time corresponding to the Late Preclassic and Early Classic of Mesoamerica. We located and studied nine sites where shaft-and-chamber tombs had reportedly been discovered and looted, but here we focus on three (El Reparito, El Pozo de Doña Amparo, and La Pedrera) where we were able to excavate un-looted as well as partially looted shaft-and-chamber tombs. In the process we obtained evidence of (1) the location and type of soil selected for the excavation of such tombs; (2) variation in the form and content of the shafts and tomb chambers; (3) the tools used for digging and the manner of sealing such tombs; (4) chronological placement of the tombs; (5) burial of infants, sub-adults, and adults in the chambers; (5) pathology in the pre-Hispanic population responsible for such tombs; (6) cremation of bodies and their curation for different periods of time before incineration; and (7) alternative forms of interment along with shaft-and-chamber tombs in the same cemetery. Also, the data obtained lend support for the idea that the Ameca River and the Banderas Valley formed a "soft frontier" at this time between fairly distinct pre-Hispanic cultural traditions found to the north and to the south of the river, an area in which there was some intermixing of these traditions.
\end{abstract}

In 1986 one of the authors (Mountjoy) began an archaeological project in the Banderas Valley focused on the investigation and conservation of the pre-Hispanic site of Ixtapa (PV-1, see master map, Figure 1). The project also involved the localization and evaluation of other archaeological sites in the municipality of Puerto Vallarta. The investigations at Ixtapa revealed a long history of indigenous habitation at that site, beginning sometime around 300 B.C. and ending around A.D. 1600 (Mountjoy 1993, 2004; Mountjoy et al. 2003). Within the temporal span of indigenous habitation it was possible to distinguish at least five distinct archaeological cultures, roughly corresponding to the Mesoamerican phases of the Middle Formative, Late Formative/Early Classic, Late Classic, Early Postclassic, and Late Postclassic. The first ceremonial mounds at Ixtapa, mounds of earth and river cobbles, were constructed about A.D. 800, during the Late Classic phase, but between A.D. 1100 to A.D. 1200, in the Early Postclassic, the ceremonial center there grew considerably as a consequence of its development as the principal center of the Aztatlan archaeological culture on the southern side of the Banderas Valley. From that time on, throughout the Late Postclassic and into the Spanish colonial period, the site of Ixtapa appears to have remained the largest and most important pre-Hispanic center on the southern side of the Banderas Valley.

During the archaeological investigations at Ixtapa, fragments of pottery vessels were found of the same types of decorated Late Formative/Early Classic pottery often placed as offerings in shaft-

E-mail correspondence to: jbmountj@hotmail.com and-chamber tombs in the State of Nayarit across the Ameca River to the north, as well as in such tombs in the highlands of Jalisco to the east. Also found were types of decorated pottery like those often placed as offerings in tombs not of the shaft-and-chamber type found in sites to the south of the Banderas Valley, along the coast of Jalisco and into Colima. In part because of this, it was proposed that the Ameca River, the river that divides the Banderas Valley between the states of Jalisco and Nayarit, may have been a "soft frontier" between two distinct cultural traditions during the Late Formative/Early Classic, and that in this frontier zone there was a mixture of burial practices characteristic of these two archaeological traditions (Mountjoy 1993).

Unfortunately, it was not possible to test this hypothesis with the data from the excavations in Ixtapa because no Late Formative/ Early Classic burials were found there, although burials of the Middle Formative, Early Postclassic, and Late Postclassic were discovered at Ixtapa. In part because of this gap in knowledge about Late Formative/Early Classic mortuary patterns, it was decided to dedicate a major part of the 1993 field season to the search for burials of this period, especially those of the shaft-andchamber tomb type.

Elerth Erickson reported the presence of simple shaft-andchamber tombs on the south (Jalisco) side of the Banderas Valley in 1969 or 1970 (Evans 1971:25; Kan, Meighan, and Nicholson 1989:32), but their presence had never been verified and systematically studied by an archaeologist. Also, the presence such tombs on the south side of the Ameca River would help fill in the area south of the commonly mentioned "Tomb Arc of West Mexico" 


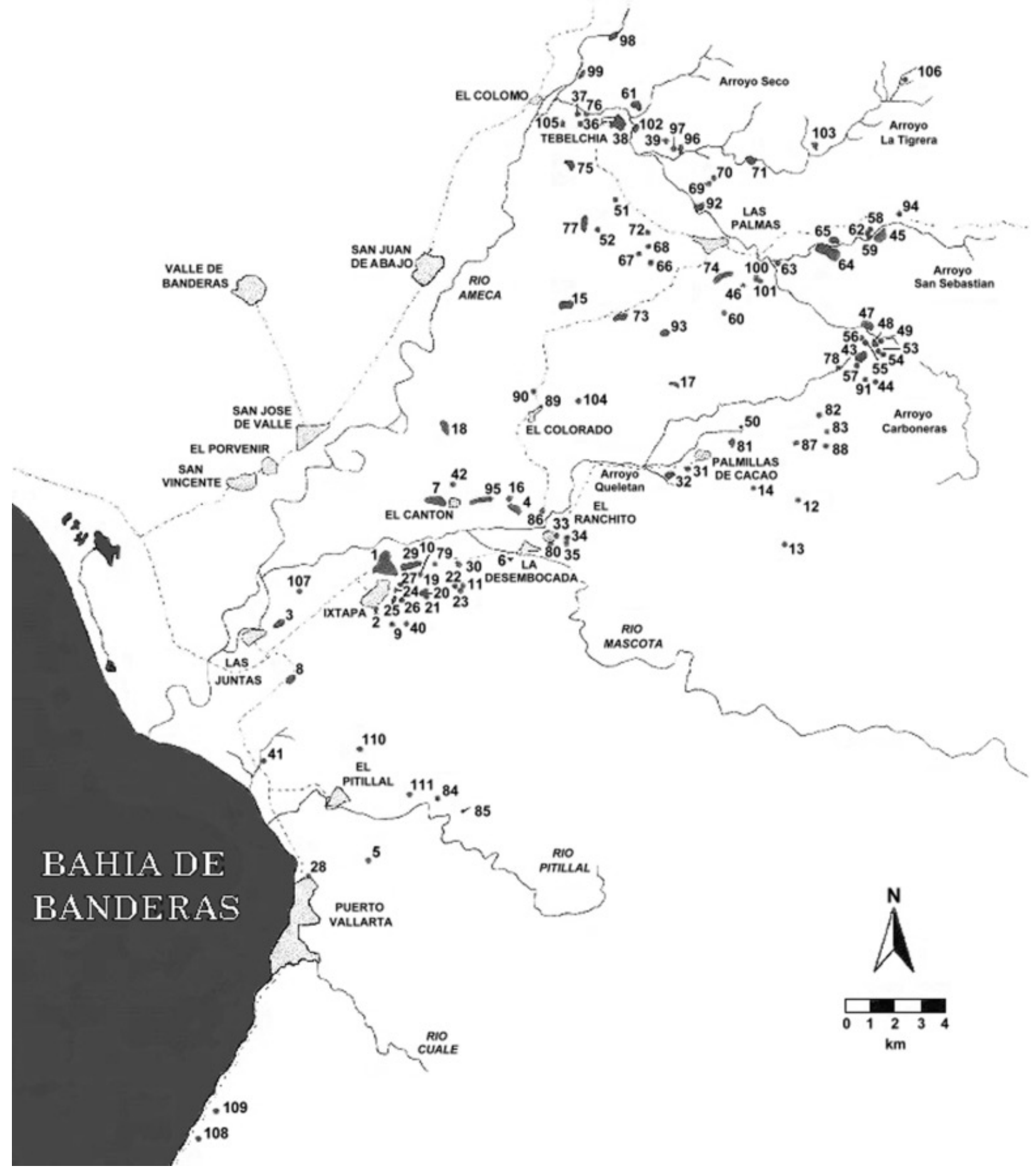

Figure 1. Map of the location of sites registered in the Municipality of Puerto Vallarta.

(Kan, Meighan, and Nicholson 1989:10), an arc of geographical distribution of shaft tombs west of which shaft-and-chamber tombs had not been found (Kan, Meighan, and Nicholson 1989) and where the ceramics were more typically of the Tuxcacuesco tradition (Kelly 1949; Mountjoy 2000). For example, they were not found during extensive investigations in the Tomatlan Valley (Mountjoy 1982) of the central coast and piedmont, in the area of the Morett site at the Jalisco/Colima border on the coast (Meighan 1972), nor in the Autlan-Tuxcacuesco area of southeastern Jalisco (Kelly 1949).

Therefore, the field season of 1993 was dedicated to locating and studying sites of shaft-and-chamber tombs, and one of us (Mountjoy) began with the investigation of a site called El Reparito (PV-45, see master map, Figure 1) near the town of Las 
Palmas where according to an informant about 20 years earlier some people from Las Palmas found and looted several tombs, some of which appeared from his description to have been of shaft-and-chamber type. He, at that time a teenager, had been hired to help with the digging.

The informant took Mountjoy to the site of El Reparito, and afterwards Mountjoy located and interviewed two of the other people who excavated there. Based on the information obtained from these people, and using their expertise in the field, Mountjoy conducted excavations at El Reparito in an attempt to verify their accounts, encountering the remains of three looted shaft-andchamber tombs and three shaft-and-chamber tombs that had not been found by the earlier excavators. After finishing the explorations at El Reparito, Mountjoy and crew continued investigating and excavating at other sites where local excavators reported having found shaft-and-chamber tombs. This led to the excavation of the remains of looted shaft-and-chamber tombs in Cajón Morado (PV-64, see master map, Figure 1), and two un-looted shaft-andchamber tombs in the site called El Pozo de Doña Amparo (PV67, see master map, Figure 1).

In the field season of 1994, Mountjoy and crew continued with the investigation of sites reported to have contained shaft-andchamber tombs, and at one of these sites, called El Rincón (PV46, see master map, Figure 1), they excavated what appeared to be the remains of one looted shaft-and-chamber tomb. Also in 1994, they excavated an extremely simple shaft-and-chamber tomb at the site of La Pedrera (PV-28, see master map, Figure 1), as well as Late Formative/Early Classic tombs of other kinds at the sites of La Pedrera and El Colorado (PV-89, see master map, Figure 1). By the end of the 1994 field season, Mountjoy and crew had inspected and registered all nine sites in the Municipality of $\mathrm{Pu}-$ erto Vallarta in which shaft-and-chamber tombs had reportedly been found, and Sandford studied the skeletal remains that we recovered from some of these sites.

In the process of locating and studying sites with shaft-andchamber tombs in the southern half of the Banderas Valley, we came to understand not only various aspects of the burial practices associated with the shaft-and-chamber tombs but also something about the range of mortuary customs of the Late Formative/Early Classic period within which tombs of the shaft-and-chamber type were one of the options for burial. Utilizing data from excavations in three sites (El Reparito, El Pozo de Doña Amparo, and La Pedrera), we report here various aspects of the shaft-and-chamber tomb mortuary pattern discovered at sites in the Municipality of Puerto Vallarta in the Banderas Valley, including their location, arrangement, form, funerary offerings, dating, and the preliminary analysis of the human remains found therein. Also included is a discussion of the other options for burial utilized during the Late Formative/Early Classic period that are often found in the same cemeteries that have shaft-and-chamber tombs.

\section{EL REPARITO}

The excavation of tombs at El Reparito (Figure 1, PV-45; Figure 2) took place about 1970-1971, and it was said to have begun when one of the local men who was accustomed to participating in looting parties of 19-26 men from the town of Las Palmas accidentally found a stone shaft about $80 \mathrm{~cm}$ high sticking out of the ground on the slope of a hill. Knowing that such stones were often used in pre-Hispanic times to mark the spot of a tomb, this man

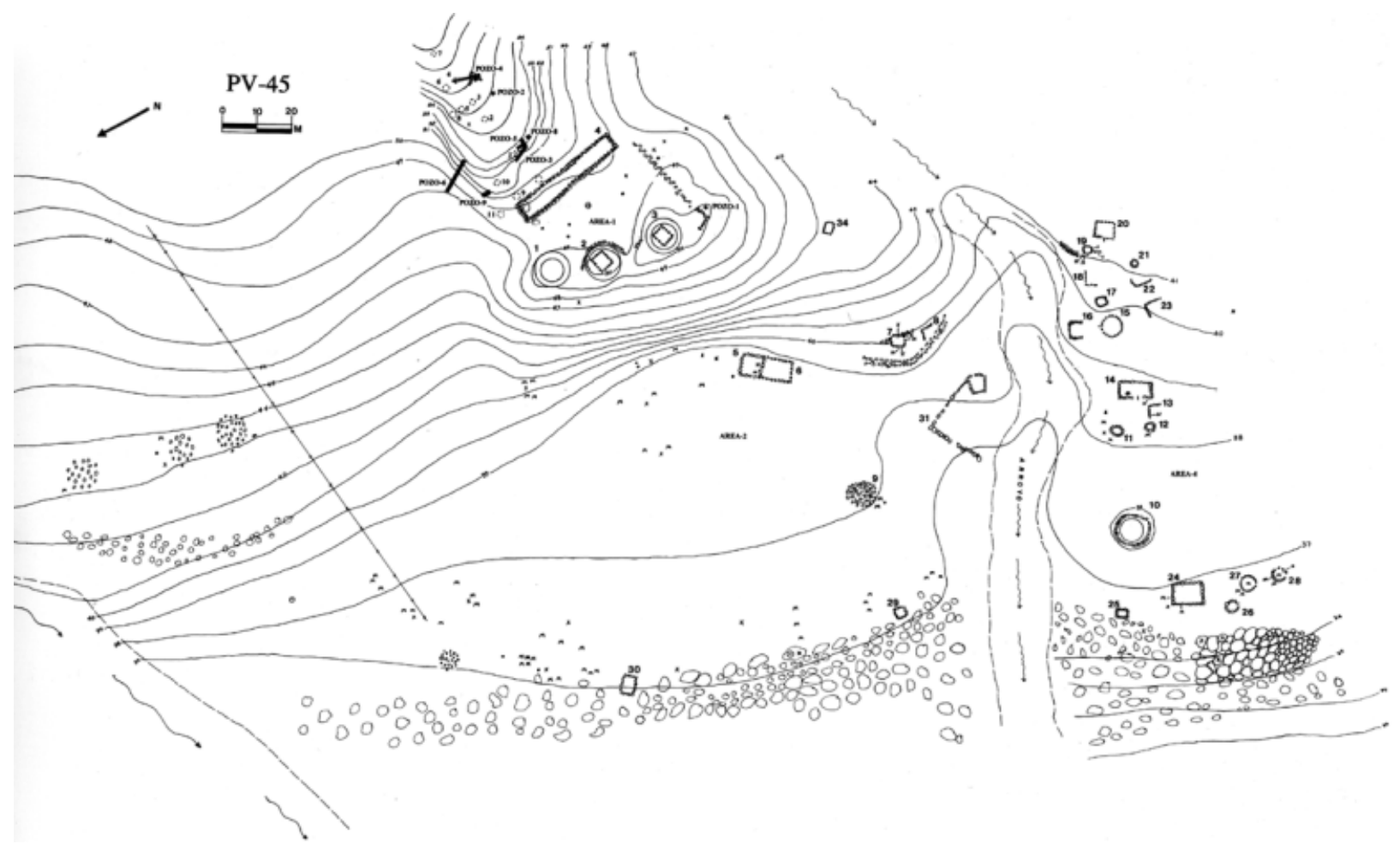

Figure 2. Map of the El Reparito (PV-45) site. Key: "O" = looted tomb; " $\mathrm{x}^{\prime \prime}=$ metate grinding stone; ${ }^{\prime \prime}$." = mano grinding stone; $O=$ morter/molcajete; " $\mathrm{M}^{\prime \prime}=$ maul; $\mathrm{O}=$ grinding depression on boulder; $\mathrm{O}=$ boulder with petroglyphs, and "pozo" = our excavations. 
solicited the help of two other local looters and they set to work excavating underneath the stone, removing earth to the depth of about $3 \mathrm{~m}$ in what turned out to be the shaft of a shaft-andchamber tomb.

At the bottom of the shaft, these men reportedly found human bones, pottery figurines, and other offerings. Then they began to excavate in the sides of the shaft, and on the side toward the ascending slope of the hill they found two stone slabs that were covering the doorway of a chamber. Inside the chamber they found four or five human burials accompanied with many funerary offerings, including hollow pottery figurines with "tattoo-like" designs on the face and body.

Having finished their excavation of the first tomb, the men began moving up the slope with their excavation, finding some ten or eleven tombs, at least eight of which were of the shaft-andchamber type. Indeed, in our inspection of the slope we found several stone slabs that probably once sealed tomb entrances. On the surface of one of these slabs we found the pecked design of an animal, possibly a dog, standing over a pit that probably represents the sun (Figure 3). Some of the other tombs the men found were simple pits without a chamber. They stated that they found what appeared to be tombs that had neither bones nor offerings inside. In one of these they found only a fill of burned clay fragments.

These men told me that they found a great variety of offerings of pottery in the tombs, including cups, bowls, jars, whistles, pipes,

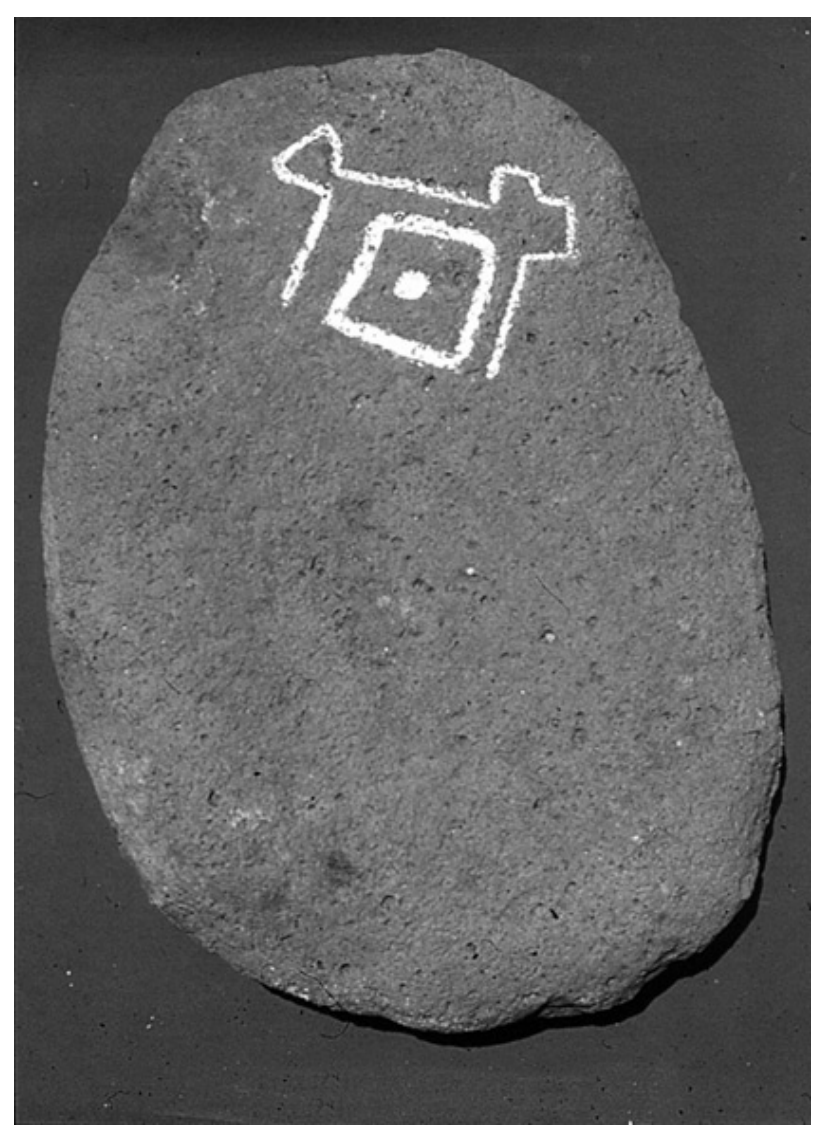

Figure 3. Shaft-and-chamber tomb door with petroglyph, found on the surface in the area of looted tombs at the El Reparito (PV-45) site. Height $53 \mathrm{~cm}$, thickness $10 \mathrm{~cm}$. and spindle whorls. They also found many objects made of stone, including slate mirror backs, iron pyrites, and projectile points and knives of obsidian. Most of these objects of pottery and stone were sold to a man from Guadalajara who trafficked in preHispanic objects, and who flew to Las Palmas in a small private airplane to pick up crated loads of looted tomb offerings. Fortunately, one lot of archaeological pieces that had been excavated from tombs at El Reparito was photographed in the back yard of one of the looters while he awaited the arrival of the airplane (Figure 4). Thanks to this photo, it has been possible to verify much of the information provided by the excavators.

We began our excavations at El Reparito on the southeastern edge of the area excavated by the looters, proceeding with our excavation toward the southeast in a part of the site supposedly unexplored by the looters. The subsoil here, derived from the decay of volcanic rhyolite, turned from a yellowish color that did not damage the surface of pottery offerings to a reddish color that did damage the surface of the pottery offerings and thus considerably diminished their commercial value. The pre-Hispanic inhabitant's predilection for searching out the yellowish rhyolitic subsoil for digging their shaft-and-chamber tombs is so well known by the looters that they call such subsoil "tierra monera" (soil where figurines can be found). In this site, the shaft-and-chamber tomb burials were placed in the sloping hillside immediately to the east of the habitation area (Figure 2).

This practice of shaft tomb burial in cemeteries located outside of the habitation area seems to have been common in the sites we studied in the Banderas Valley, a finding reinforced by a site survey in the adjacent Municipality of San Sebastián del Oeste and through excavations at cemeteries containing shaft-and-chamber tombs in the Mascota Valley to the east of the Municipality of Puerto Vallarta during the 2005 field season.

Very soon, our excavation encountered an oval shaft $1.30 \times$ $1.15 \mathrm{~m}$ in diameter, and at the bottom of the shaft, at $1.80 \mathrm{~m}$ depth, we found a group of eight river-worn stone slabs. In front of these slabs was a stone tool that may have been used to dig the shaft (Figure 5). In the small chamber beneath the slabs we found tiny fragments of human bone and an offering consisting of two pottery vessels: a small red jar and an eroded squash-form bowl (Table 1, 45-1).

We continued to excavate toward the southeast and found a second shaft in the process. At the bottom of this triangularly shaped shaft, at the depth of $2.45 \mathrm{~m}$ from the surface of the ground, we found two river-worn stone slabs that sealed the door of a small chamber that was dug off vertically from the bottom of the shaft (Figure 6). The spaces between these two slabs and their edges had been sealed with chunks of subsoil and stone cobbles. In front of the stone slabs we found a group of burned human bones, probably from the cremated body of a sub-adult. The analysis of carbon recovered in association with these bones yielded a date of A.D. $340 \pm 60$ years (Beta-68304, calibrated to A.D. 330 to A.D. 585 at $95 \%$ confidence, with the calibration intersect at 430 A.D.; Table 1, 45-2).

Associated with the bones discovered at the bottom of the shaft was an offering of four pottery vessels and a spindle whorl. The surface of all the vessels was in poor condition, apparently from the effects of the acidic reddish subsoil and of water that had accumulated in the bottom of the shaft. Also, three of the vessels had been broken by the weight of the earth that had been used to fill the shaft. The group of pottery vessels included a orangeslipped tripod jar; a jar and a bowl with white, black, and red 


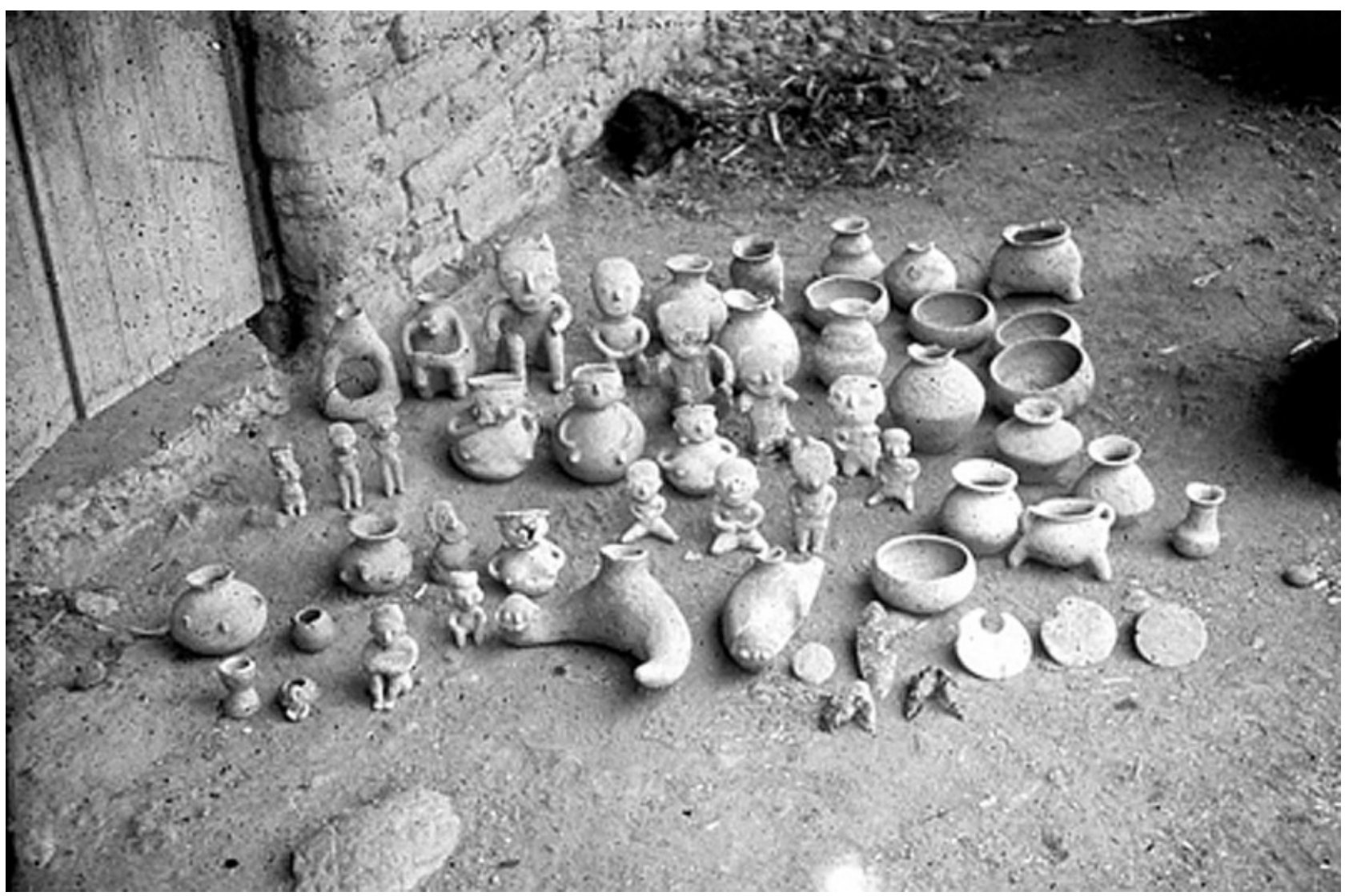

Figure 4. Photograph of a collection of tomb offerings looted from tombs at the El Reparito (PV-45) site about 1970 to 1971.

painted designs on orange slip; and a bowl with white and red decoration on an orange slip. In the small chamber behind the stone slabs we found another group of burned bones in a matrix that resembled toothpaste, and two eroded pottery vessels: a plain ware bowl and a bowl painted white on orange on a cream-colored slip (Table 1, 45-2).

Continuing our excavations at El Reparito, we explored three of the shaft-and-chamber tombs that had been looted. The large door of one of these tombs (Table 1, 45-3) had been sealed up with a wall of river cobbles. Inside we found some remains left by the looters, including the broken remains of a bowl of the type classified as Gavilán Polychrome at the Amapa site in central coastal Nayarit (Grosscup 1976: 223-224), a ring of volcanic stone about the size and shape of a napkin ring and incised with simple designs, and one shark's tooth. The bones associated with the shaft area included those of an infant less than 5 years of age. Human remains in the chamber indicate that burial consisted of at least one adult and two sub-adults. One of the sub-adults was only 5 or 6 years of age at the time of death. The bodies of these individuals had been cremated. Moreover, the patterns of transverse cracking and irregular splitting of the bone fragments suggest that they were burned while covered with flesh (Ubelaker 1989).

Among the contents left by the looters of another shaft-andchamber tomb (Table 1,45-4) we found the remains of at least one adult and two sub-adults. The cranial bones of the adult showed some thickening and porosity consistent with the findings in porotic hyperostosis, which is often attributed to iron deficiency anemia. The bones of the three individuals buried in this tomb also indicate cremation. In the same tomb, at a depth of $2.0 \mathrm{~m}$ and inside the chamber, we found one large obsidian projectile point, a fragment of a second, as well as sherds of the same orange-slipped red, black, and white decorated pottery recovered from the area in front of the intact shaft-and-chamber tomb (Table 1, 45-2).

In the area of another looted tomb (Table 1, 45-5), in which the exact location of the shaft and the chamber were no longer discernible, we recovered six human bones and most of the slate backing for a pyrite mirror $7.9 \mathrm{~cm}$ in diameter. We also found a stone axe, sherds from a red ware jar and a plain ware bowl, and one four-footed metate that was probably either used to close the chamber door, or was left as an offering with the deceased.

We also excavated (Table 1, 45-6) one small unlooted chamber that contained cremated human bones, unaccompanied by any nonperishable offerings, although there were remains of one adult burial in the shaft, accompanied by an orange-slipped squashform jar.

\section{EL POZO DE DOÑA AMPARO}

El Pozo de Doña Amparo (Figure 1, site 67; Figure 7) takes its name from the woman who found the first shaft-and-chamber tomb in the area of the town of Las Palmas. According to local informants, one day when Doña Amparo and two other women were cutting nopal cactus pads along a trail that cut through the archaeological site, she found a sunken area where some stone shafts 


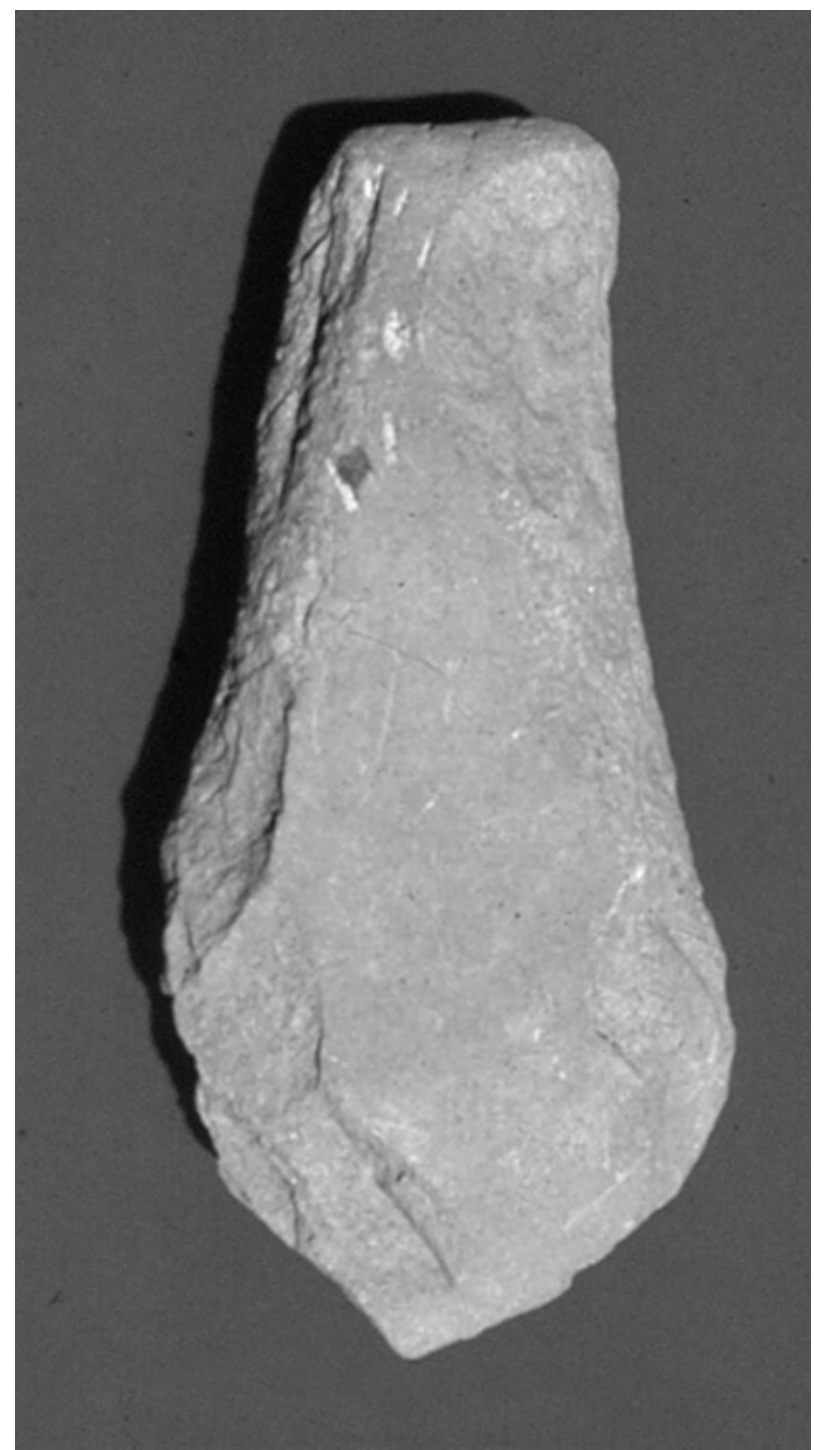

Figure 5. Stone tool believed to have been used to excavate one of the shaft-and-chamber tombs at the El Reparito (PV-45) site. Length $22.5 \mathrm{~cm}$, thickness $4.8 \mathrm{~cm}$.

were sticking out of the ground. The following day she returned with her sons who brought metal digging rods to explore the spot. They removed the stone slabs and excavated below them, eventually perforating the chamber of a tomb and, in the process, breaking two large hollow figurines that had been placed in the tomb as offerings. From this chamber they managed to recover some unbroken bowls and jars.

This discovery caught the attention of several men from Las Palmas who had been excavating, without success, in pre-Hispanic sites in the area. After the accidental discovery made by Doña Amparo and her sons, these men realized that indeed there could be found tombs with pottery figurine offerings in their area, they obtained the services of an expert looter known as a "monero," who lived in a distant village (San Felipe de Hijar) to the east, to help them find more such tombs. This monero had relatives in Las Palmas with whom he could obtain lodging, but he was also provided a "salary" consisting of all the food, liquor, and female companionship he required during his stay. He lived in Las Palmas for approximately a year and a half while he directed a sort of local "field school," showing some 12 to 16 men how to locate and properly excavate tombs.

The monero also inspected the Pozo de Doña Amparo tomb and found a second chamber extending off the shaft on the opposite side from the first. This second chamber had a door formed of two large stone slabs, which he removed. He then managed to recover the offerings from this tomb intact. He and his "students" then moved their excavation to the slopes north of the original tomb, an area where they could see the mouths of jars and parts of some pottery figurines on the surface of the ground where they were being uncovered by erosion. With a field crew of 16 men, excavations were begun along a stone retention wall, and from there the looters moved up the slope to the west (Figure 7).

In this systematic exploration they found an estimated 25 tombs, arranged equally spaced about 3.0-3.5 $\mathrm{m}$ apart in a "checkerboard" fashion, many of which were apparently of shaftand-chamber type. Although these tombs were not found at great depth, this was probably due to the severe sheet erosion at this location, erosion that may have removed more than a meter of overlying soil in recent years. Rather than finding the entrance to the tombs sealed with slabs of river rock, the doorways were sealed instead with footed metates. In contrast to other sites, such as El Reparito, all these chambers came directly off the shaft without being stepped down to a slightly lower level. The offerings found in the chambers, according to an informant, included knives and spear points of obsidian, beads, hollow pottery figurines painted with stripes or tattoo-like designs on the face, as well as solid flat pottery figurines, jars painted with stripes, and small painted bottles.

When they had finished the excavation of this cemetery, the diggers began to explore the area to the southwest of the tomb found by Doña Amparo, where they found an isolated shaft-andchamber tomb on the edge of the top of a low hillock (Figure 7). Before they could finish their exploration of this part of the site, they were told about the possibility of more tombs in a place called El Rincón. They decided to move their operation to El Rincón because it seemed that the Pozo de Doña Amparo site was pretty well played out. Also, they were uneasy because their digging so near the footpath that crossed through this area was drawing a lot of unwanted attention.

Taking advantage of information we obtained about areas of the Pozo de Doña Amparo site that had not been explored by the looters, we began excavating small test pits in those areas. Of some 40 to 50 such test pits, we only found abundant potsherds in five. We then expanded each of these five pits in search of shaftand-chamber tombs.

Our first large-scale excavation was carried out on the top of a hillock, where we discovered a solitary shaft (Figure 7; Table 1, 67-1). At the depth of only $5 \mathrm{~cm}$ into the shaft we found the remains of a large broken jar. As we continued excavating around the jar we began to find fragments of human bones. Enlarging the excavation in the shaft and continuing downward, we found the remains of three pottery bowls, two of them decorated with stripes of red paint over a cream-colored slip, and a third decorated with orange paint on the natural brown of the pottery paste. The redon-cream decorated pottery is similar to pottery found at the La Pintada site in the Tomatlán (Jalisco) valley to the south and dated there between 190 B.C. and 300 A.D. (Mountjoy 1989), as well as pottery found in the Huitzilapa, Jalisco shaft-and-chamber tomb 
Table 1. Basic information on shaft-and-chamber tombs excavated in the municipality of Puerto Vallarta

\begin{tabular}{|c|c|c|c|c|c|c|c|}
\hline $\begin{array}{l}\text { Site Name \& } \\
\text { Tomb Designation }\end{array}$ & $\begin{array}{l}\text { Description } \\
\text { of Shaft }\end{array}$ & $\begin{array}{l}\text { Human Remains } \\
\text { in Shaft }\end{array}$ & $\begin{array}{l}\text { Mortuary Offerings } \\
\text { in Shaft }\end{array}$ & $\begin{array}{l}\text { Descripton } \\
\text { of Tomb Door }\end{array}$ & $\begin{array}{l}\text { Description } \\
\text { of Tomb }\end{array}$ & $\begin{array}{l}\text { Human Remains } \\
\text { in Tomb }\end{array}$ & $\begin{array}{l}\text { Mortuary Offerings } \\
\text { in Tomb }\end{array}$ \\
\hline $\begin{array}{l}\text { 45-1, El Reparito, } \\
\text { Pit \#5, Feature \#1 }\end{array}$ & $\begin{array}{l}\text { Form: oval, Dia: } \\
1.15 \mathrm{~m} \times 1.30 \mathrm{~m} \\
\text { Depth: } 1.80 \mathrm{~m}\end{array}$ & & small plainware jar & $\begin{array}{l}8 \text { slab-shaped river } \\
\text { cobbles }\end{array}$ & $\begin{array}{l}\text { Shape:boot?/bottle, Dia: } \\
1.15 \mathrm{~m} \times 1.30 \mathrm{~m}\end{array}$ & $\begin{array}{l}\text { MNI: } 1 \text { individual; tiny } \\
\text { fragments. }\end{array}$ & $\begin{array}{l}1 \text { squash-form bowl; } \\
1 \text { small redware jar }\end{array}$ \\
\hline $\begin{array}{l}\text { 45-2, El Reparito, } \\
\text { Pit \#5, Feature \#2 }\end{array}$ & $\begin{array}{l}\text { Form: triangular, } 1.55 \mathrm{~m} \\
\text { on a side, Depth: } 2.45 \mathrm{~m}\end{array}$ & $\begin{array}{l}\text { MNI: } 1 \text { individual; } \\
\text { cremated bone }\end{array}$ & $\begin{array}{l}1 \text { orange slipped tripod } \\
\text { jar; } 1 \text { jar and two bowls } \\
\text { of Reparito Polychrome; } \\
1 \text { incised biconical } \\
\text { spindle whorl }\end{array}$ & $\begin{array}{l}2 \text { large slab-shaped river } \\
\text { cobbles; small cobbles } \\
\text { and chunks of subsoil }\end{array}$ & $\begin{array}{l}\text { Shape: boot, Depth: } \\
1.14 \mathrm{~m} \text {, Width: } .92 \mathrm{~m} \text {, } \\
\text { Height: } 1.2 \mathrm{~m}\end{array}$ & $\begin{array}{l}\text { MNI: } 1 \text { individual, poss } \\
\text { cremated bone }\end{array}$ & $\begin{array}{l}1 \text { white on orange on } \\
\text { cream slipped bowl; } \\
1 \text { plainware bowl }\end{array}$ \\
\hline $\begin{array}{l}\text { 45-3, El Reparito, } \\
\text { Pit \# 5, Feature 3, } \\
\text { Looted Tomb }\end{array}$ & Depth: $2.85 \mathrm{~m}$ & & & $\begin{array}{l}\text { single line rock wall of } \\
\text { large river cobbles }\end{array}$ & $\begin{array}{l}\text { Shape: boot, Depth: } \\
1.10 \mathrm{~m} \text {, Width: } 1.50 \mathrm{~m}\end{array}$ & $\begin{array}{l}\text { MNI: } 1 \text { infant under } \\
5 \text { yrs outside of tomb } \\
\text { door; cremated bone; } \\
1 \text { adult inside tomb, } \\
\text { cremated bone }\end{array}$ & $\begin{array}{l}\text { fragments of a Gavilan } \\
\text { Polychrome bowl; frag- } \\
\text { ments of a bule-shaped } \\
\text { jar of El Reparito Poly- } \\
\text { chrome; } 1 \text { piece of slate } \\
\text { backing for a pyrite } \\
\text { mirror; } 1 \text { napkin ring } \\
\text { like object of porous red } \\
\text { volcanic stone decorated } \\
\text { with incisions; } 1 \text { shark } \\
\text { tooth }\end{array}$ \\
\hline $\begin{array}{l}\text { 45-4, El Reparito Pit \#4, } \\
\text { Looted Tomb \#4 }\end{array}$ & $\begin{array}{l}\text { Form: oval, Depth: } \\
2.00 \mathrm{~m}\end{array}$ & & & & $\begin{array}{l}\text { Shape: boot, Length: } \\
2.00 \mathrm{~m} \text {, Width: } 1.30 \mathrm{~m}\end{array}$ & $\begin{array}{l}\text { MNI: } 1 \text { adult; } 2 \text { sub } \\
\text { adults, cremated bone }\end{array}$ & $\begin{array}{l}11 \text { sherds of Reparito } \\
\text { Polychrome; } 2 \text { obsidian } \\
\text { projectile points }\end{array}$ \\
\hline $\begin{array}{l}\text { 45-5, El Reparito Pit \#3, } \\
\text { Looted Tomb \#1 }\end{array}$ & $\begin{array}{l}\text { Form: oval, Dia: } \\
1.60 \mathrm{~m} \times 2.07 \mathrm{~m}, \\
\text { Depth: } 1.30 \mathrm{~m}\end{array}$ & & & footed metate? & $\begin{array}{l}\text { Shape: boot?/bottle?, } \\
\text { Dia: } 1.60 \mathrm{~m} \times 2.07 \mathrm{~m}\end{array}$ & MNI: 1 individual & $\begin{array}{l}\text { slate back of pyrite } \\
\text { mirror; stone axe; red- } \\
\text { ware jar; plainware } \\
\text { bowl. }\end{array}$ \\
\hline 45-6, El Reparito, Pit \#9 & $\begin{array}{l}\text { Form: oval Depth: } \\
1.78 \mathrm{~m}\end{array}$ & MNI: 1 adult & $\begin{array}{l}\text { fragments of } 1 \text { orange } \\
\text { slipped squash form jar }\end{array}$ & none & Shape: cave-like & MNI: 1 individual & none \\
\hline $\begin{array}{l}\text { 67-1, Dona Amparo, } \\
\text { Pit \#1 }\end{array}$ & $\begin{array}{l}\text { Form: oval, irregular, } \\
\text { Dia: } 1.43 \mathrm{~m} \text {, Depth: } \\
1.15 \mathrm{~m}\end{array}$ & $\begin{array}{l}\text { MNI: } 2 \text { adults, } 125- \\
35 \text { yrs, } ; 2 \text { sub-adults, } \\
17-11 \text { yrs, } 1 \text { under } \\
7 \text { yrs, cremated bone }\end{array}$ & $\begin{array}{l}1 \text { plainware jar; } 1 \text { or- } \\
\text { ange on buff bowl; } \\
2 \text { Amparo Red on Cream } \\
\text { bowls }\end{array}$ & 2 thin round stone slabs & $\begin{array}{l}\text { Shape: boot, steps } \\
\text { present, Depth: } 1.45 \mathrm{~m} \text {, } \\
\text { Length: } 2.20 \mathrm{~m} \text {, Width: } \\
.70 \mathrm{~m} \text {, Height: } .70 \mathrm{~m}\end{array}$ & $\begin{array}{l}\text { MNI: } 3 \text { adults, } 1 \text { male; } \\
1 \text { sub-adult, } 10-15 \text { yrs; } \\
2 \text { infants; all cremated }\end{array}$ & \\
\hline $\begin{array}{l}\text { 67-2, Dona Amparo, } \\
\text { Pit \#3, Feature } 1\end{array}$ & $\begin{array}{l}\text { Form: round, Dia: } \\
1.1 \text { m, Depth: } 1.50\end{array}$ & & & $\begin{array}{l}\text { irregular stones and part } \\
\text { of a footed metate }\end{array}$ & $\begin{array}{l}\text { Shape: boot, step } \\
\text { present, Depth: } 1.67 \mathrm{~m} \text {, } \\
\text { Length: } 1.75 \mathrm{~m} \text {, Width: } \\
1.50 \mathrm{~m}\end{array}$ & $\begin{array}{l}\text { MNI: } 1 \text { individual, } \\
\text { cremated }\end{array}$ & $\begin{array}{l}1 \text { Amparo Incised cylin- } \\
\text { drical cup }\end{array}$ \\
\hline $\begin{array}{l}\text { 67-2, Dona Amparo, } \\
\text { Pit \#3, Feature } 2\end{array}$ & & & & irregular stones & $\begin{array}{l}\text { Shape: boot, step } \\
\text { present, Depth: } 1.70 \mathrm{~m} \text {, } \\
\text { Length: } .63 \mathrm{~m} \text {, Width: } \\
.63 \mathrm{~m} \text {, Height: } .63 \mathrm{~m}\end{array}$ & $\begin{array}{l}\text { MNI: } 2 \text { children, } 11 \mathrm{yr} \text {, } \\
17-8 \text { yrs; cremated bone }\end{array}$ & \\
\hline $\begin{array}{l}\text { 67-2, Dona Amparo, } \\
\text { Pit \#3, Feature } 3\end{array}$ & & & & & $\begin{array}{l}\text { Shape: boot, step } \\
\text { present, Depth: } 1.84 \mathrm{~m} \text {, } \\
\text { Length: } .88 \mathrm{~m} \text {, Width: } \\
.96 \mathrm{~m} \text {, Height: } .80 \mathrm{~m}\end{array}$ & & \\
\hline $\begin{array}{l}\text { 28-1, La Pedrera, Pit \#2, } \\
\text { Feature \#3 }\end{array}$ & $\begin{array}{l}\text { Form: round, Dia: } \\
1.20 \text { m, Depth: .70 m }\end{array}$ & & & irregular stones & $\begin{array}{l}\text { Shape: shaft \& cave, } \\
\text { Depth: } 1.27 \mathrm{~m} \text {, Length: } \\
.40 \mathrm{~m} \text {, Width: } .50 \mathrm{~m} \text {, } \\
\text { Height: } .40 \mathrm{~m}\end{array}$ & & 1 small redware jar \\
\hline
\end{tabular}




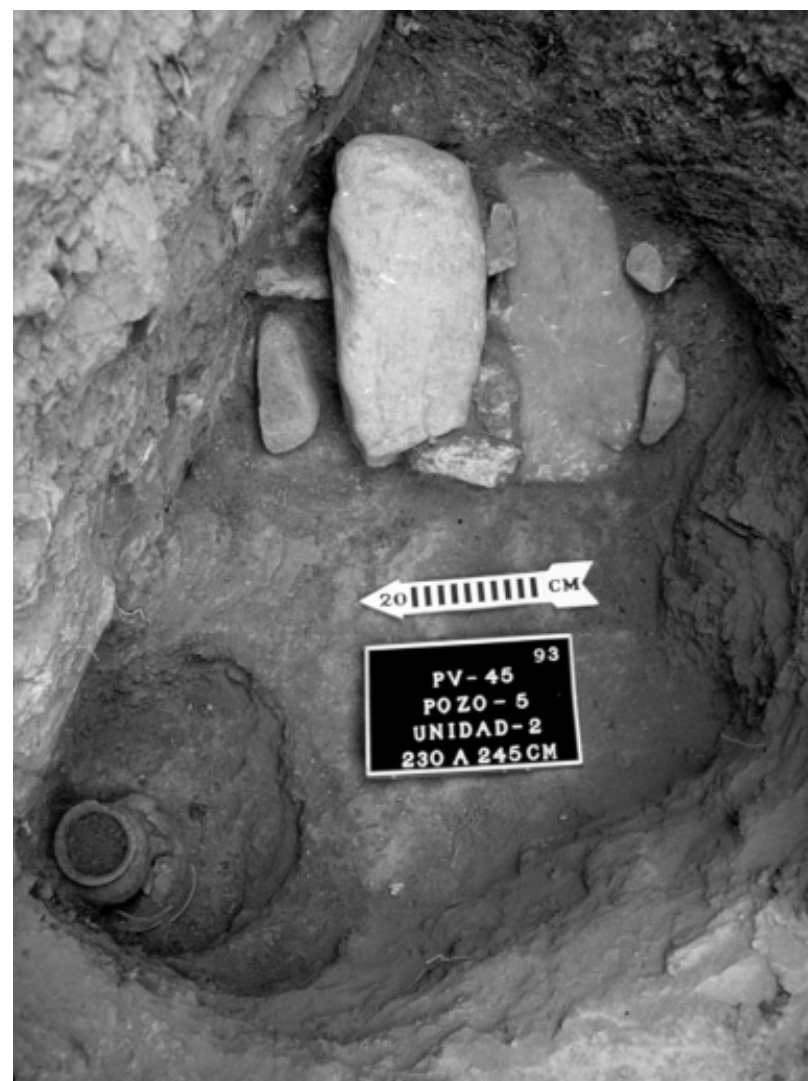

Figure 6. Shaft-and-chamber tomb discovered in excavation 5 at the El Reparito (PV-45) site, at a depth of 2.3-2.45 m below the surface of the ground. Pottery offerings located in the northwestern part of the floor of the shaft, and cremated human remains located just south of the letterboard, in front of the tomb door.

to the east and radiocarbon dated there between 1 A.D. and 300 A.D. (López et al. 1998).

Inside the third bowl we found a large burned fragment from a human skull, and we continued finding pieces of human bone and fragments of pottery all the way down to the bottom of the shaft, which we reached at a depth of $1.55 \mathrm{~m}$ below the present surface of the ground. The human bones in the shaft were found to represent at least two adults (one a male) and two sub-adults. Some of the bone, especially the mastoid process of one adult male, showed evidence of cremation. There was an inflammatory lesion on the tibia of one of the adults, similar to the type seen in treponemal infections; some cranial bone appeared thickened, with diffuse pitting, bone changes that may be seen in the early stages of treponemal disease or in iron deficiency anemia (Sandford et al. 2005).

On the north side of the shaft we found two small, thin, roundish stone slabs that had been used to seal the opening to a tomb chamber. From that level, it was necessary to step down $18 \mathrm{~cm}$ to the floor of the tomb (Figure 8). Inside, we found the jumbled cremated remains of at least three adults, one sub-adult, and two infants. Analysis of the bones indicates that the bodies were in different stages of decomposition when they were cremated, implying that the bodies were cured for different periods of time before cremation and burial. Two tibias displayed evidence of pathological inflammation of the periosteum consistent with trep- onemal infection. Also, some cranial bones had abnormal porosity that might have been caused by iron deficiency anemia or treponemal disease, and one mandible had resorbed bone and an abscess below the second molar indicative of periodontal disease. One of the femurs had an ossified spicule of bone consistent with myositis dessicans usually associated with fracture healing.

On the side of the hillock just north of the first tomb we discovered a shaft $1.1 \mathrm{~m}$ in diameter from which extended three individual chambers (Figure 7; Table 1, 67-2). All three chambers were stepped down slightly from the bottom of the shaft, and in no instance did we find stone slabs covering the entrance to the chambers. It seems likely that the entrance to these chambers was covered with some perishable material, perhaps slabs of wood or fiber mats. The perishable covering of the entrance to the eastern chamber appears to have been held in place by stones laid against the outer surface, one of which was half of a footed metate, and when the covering disintegrated, the stones fell into the chamber (Figure 9). In this chamber we found a small amorphous concentration of poorly preserved cremated bones, as well as a cylindrical pottery cup decorated with a line of cross-hatched incised triangles on the exterior just below the lip (Figure 10), of the Tuxcacuesco Incised pottery type radiocarbon dated in the Tomatlán Valley of Jalisco between 190 B.C. and 300 A.D. (Mountjoy 1989).

The opening to the north chamber may also have been closed with some perishable material that was held in place with stones. In this chamber we found the cremated remains of one adolescent and one child, without any non-perishable tomb offerings. Curiously, in the west chamber we found neither human remains nor funerary offerings.

After finishing the excavation of the west chamber, we turned to the northwest side of the shaft at a level above the north chamber where we could see fragments of pottery in the profile. At a horizontal distance of $40 \mathrm{~cm}$, we found the side of a large jar or urn that we eventually found to measure $58 \mathrm{~cm}$ in diameter. This urn was buried in a pit at the depth of $1.25 \mathrm{~m}$, and surrounding it we found what appeared to be the remains of domestic trash, including pottery sherds, obsidian scrapers, a chert core, quartzite hammer stones, fragments of metate grinding stones, and numerous burned and broken hearth stones.

It is believed that this was originally a funerary urn, perhaps used to bury the remains of an infant, although we did not find the remains of any human bones inside the urn. We did, however, find almost all of the fragments of a large cream-slipped bowl painted with a black rim and vertical red stripes, that appears to have at one time covered the mouth of the urn (Figure 11), similar to the aforementioned radiocarbon-dated red-on-cream decorated pottery from the La Pintada and Huitzilapa sites. It is important to point out the fact that some of the pottery sherds found in and around the urn had the same crosshatched incised triangle decoration that we found on the Tuxcacuesco incised cup left as an offering in the east tomb.

When the upper part of the urn collapsed, domestic trash either fell into the hole or was thrown into the hole to fill it up. This context could be interpreted to indicate that the tombs were originally excavated in a habitation area, the midden of which was subsequently eroded away, except for the trash that collapsed into the burial pit and urn. The main looted shaft-tomb cemetery, however, appears to have been located in a special area set apart from any habitations (Figure 7).

A short distance to the west of this excavation, on the same hillside, we found a pit that contained a small plain ware urn the 


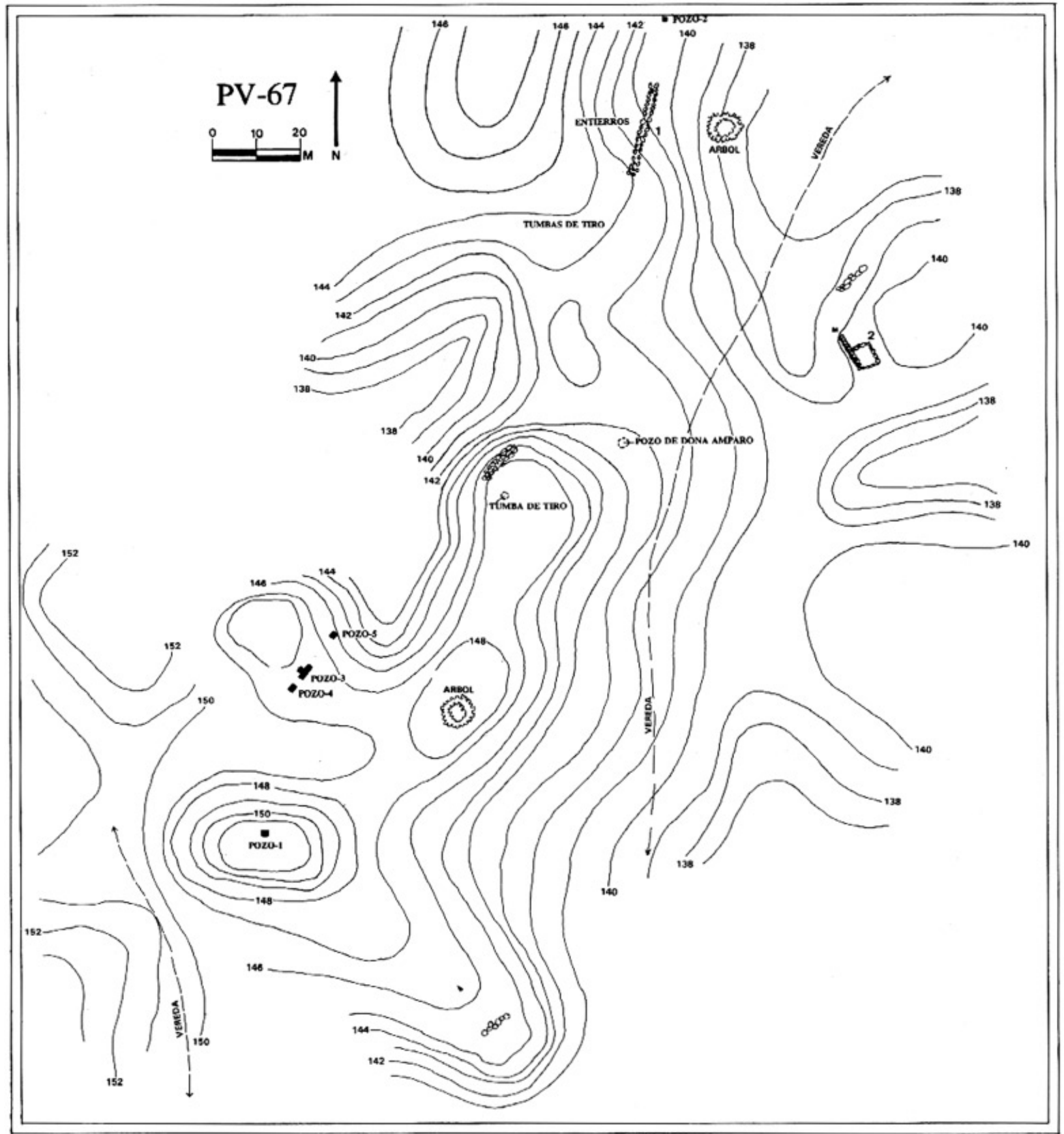

Figure 7. Map of the Pozo de Doña Amparo (PV-67) site. Key: "O" = looted tomb; "M" = maul; and "pozo" = our excavations.

mouth of which was covered by large pieces of a red-on-cream decorated bowl that had been ceremonially "killed" by punching a hole in the bottom (Figure 12). This urn also seems likely to have been used to bury the remains of an infant, but we could find no traces of human bone inside the urn.

In the area of Las Palmas what appear to be urn burials are fairly common in cemeteries that also contain tombs of the shaftand-chamber type. Thus it seems that the funerary urn was one of at least four options that the pre-Hispanic inhabitants had for burying their deceased (simple subsoil pit, urn, shaft tomb, and shaft- and-chamber tomb), although it is still not clear whether the decision to bury the (often cremated) remains of the deceased in a shaftand-chamber tomb or an urn had to do principally with the age of the deceased, his or her social position, or some other yet unknown factor.

\section{LA PEDRERA}

La Pedrera (Figure 1, PV-28; Figure 13) is a pre-Hispanic site that we registered in the northern part of the present-day city of Puerto 


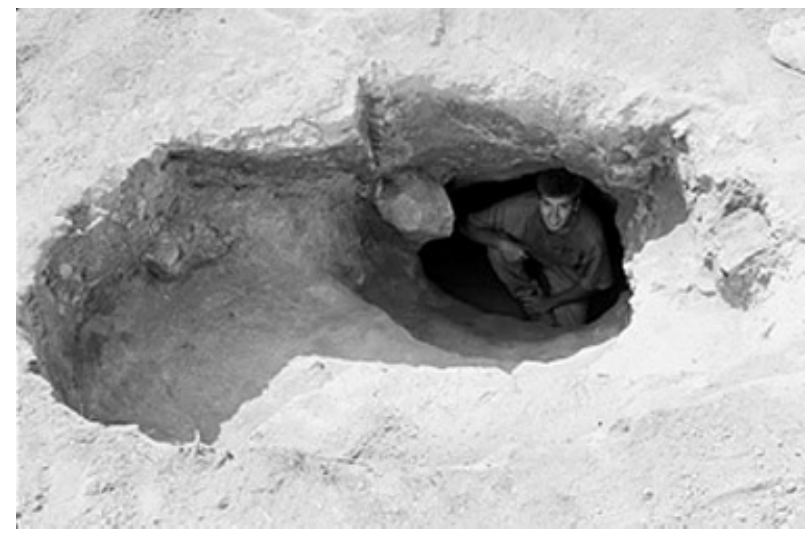

Figure 8. Shaft-and-chamber tomb discovered in excavation 1 at the Pozo de Doña Amparo (PV-67) site, at a depth of $1.55 \mathrm{~m}$ below the surface of the ground. Shawn Patch shown in the chamber.

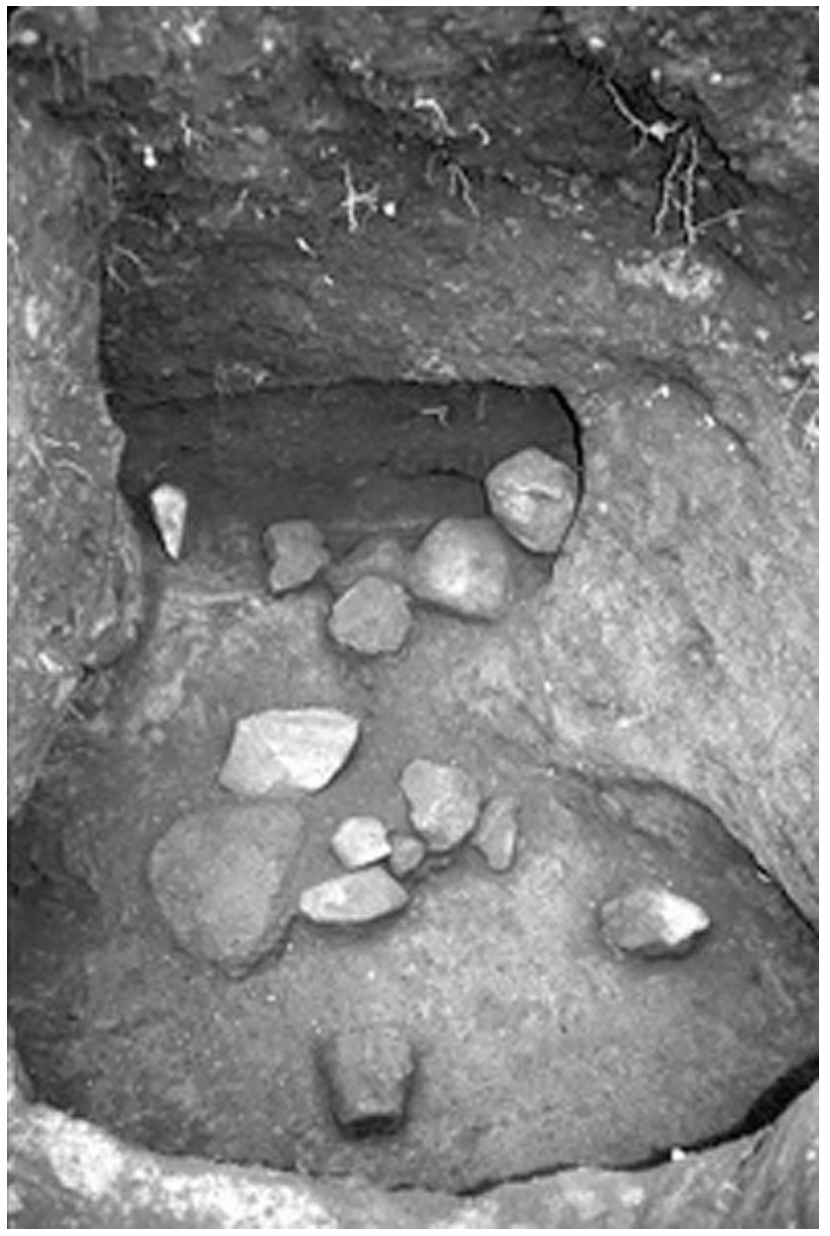

Figure 9. Shaft-and-chamber tomb discovered in excavation 3 at the Pozo de Doña Amparo (PV-67) site, at a depth of $1.75 \mathrm{~m}$ below the surface of the ground. The chamber floor is in the foreground, showing (nearest) an incised pottery cup, to the left (southeast) of which are cremated human remains. In the background is the bottom of the shaft, where rocks appear to have been placed against a perishable tomb door covering that has disintegrated, allowing some of the rocks to fall down into the chamber.

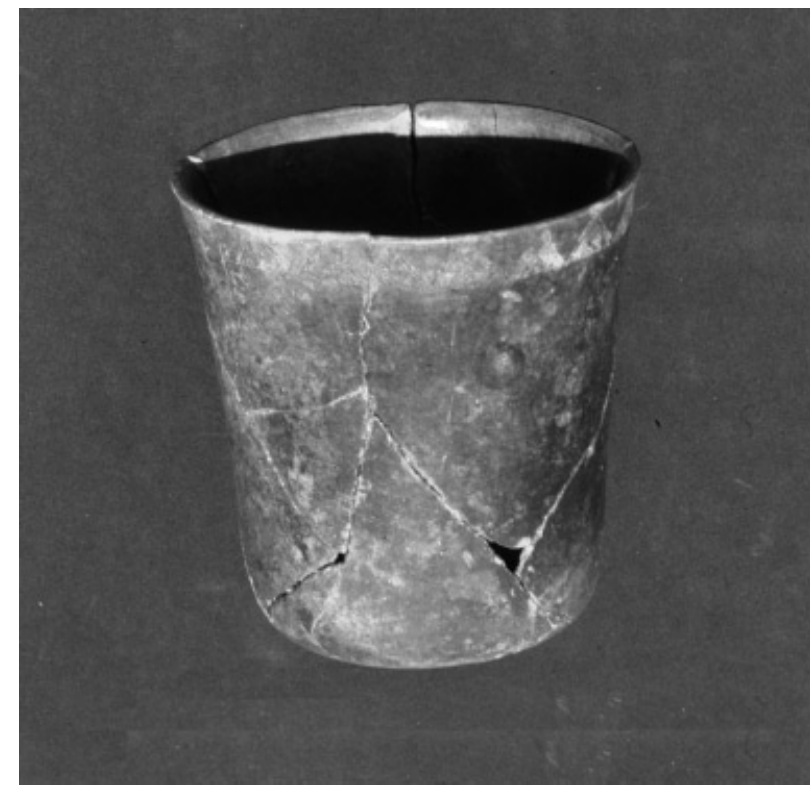

Figure 10. Incised decorated cup deposited as an offering in the eastern chamber of the shaft-and-chamber tomb discovered in excavation 3 at the Pozo de Doña Amparo (PV-67) site. Height $14.0 \mathrm{~cm}$, diameter of mouth $11.70 \mathrm{~cm}$.

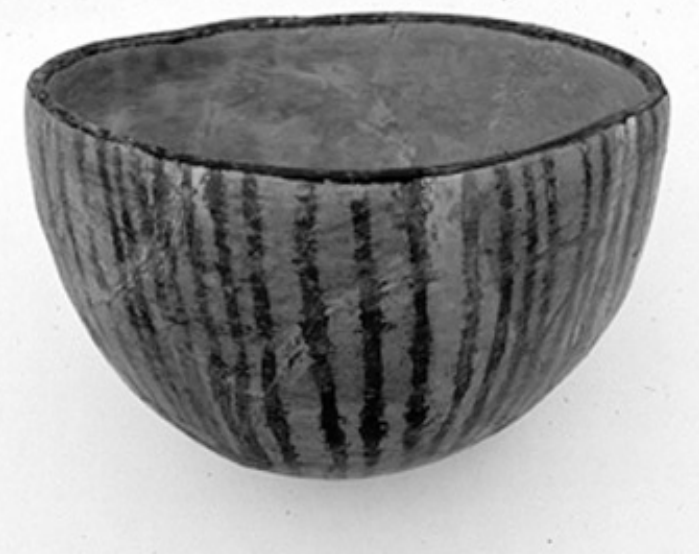

Figure 11. Large red and black-on-cream decorated bowl that once covered the mouth of an urn discovered at the bottom of a pit $1.25 \mathrm{~m}$ deep in excavation 3 at the Pozo de Doña Amparo (PV-67) site. Height, $22.5 \mathrm{~cm}$. 


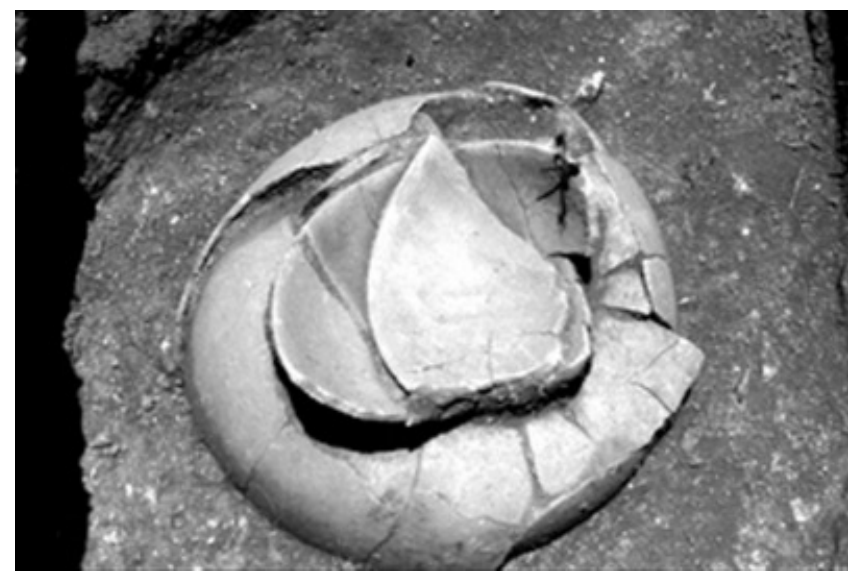

Figure 12. Small urn found in a pit at a depth of $1.06 \mathrm{~m}$ in excavation 4 at the Pozo de Doña Amparo (PV-67) site. Its mouth was covered with large pieces of an intentionally broken red-on-cream decorated bowl.
Vallarta. Exploration of the site began in 1991 after the accidental discovery of a large jar or urn by local people after the upper part of the vessel had been uncovered by heavy rainfall. A rescue operation revealed that it probably served originally as a funerary urn, but the interior was filled with earth and domestic trash that pertained to the Early Postclassic Aztatlan archaeological culture (Mountjoy 1992).

The original investigation of the La Pedrera site also revealed the presence of remains of earlier pre-Hispanic periods, notably the Middle Formative and the Late Formative/Early Classic periods. During the 1993 field season we rescued the remains of a few vessels of the Late Formative/Early Classic period that had been uncovered by a heavy rainfall on the surface of Costa Rica Street, a roadway that crosses part of the site. These vessels appeared to have been offerings for burials the bones of which had not been preserved.

When the rainy season began in 1994 we returned to the site with a man who lives on the edge of the site; later that day, on the

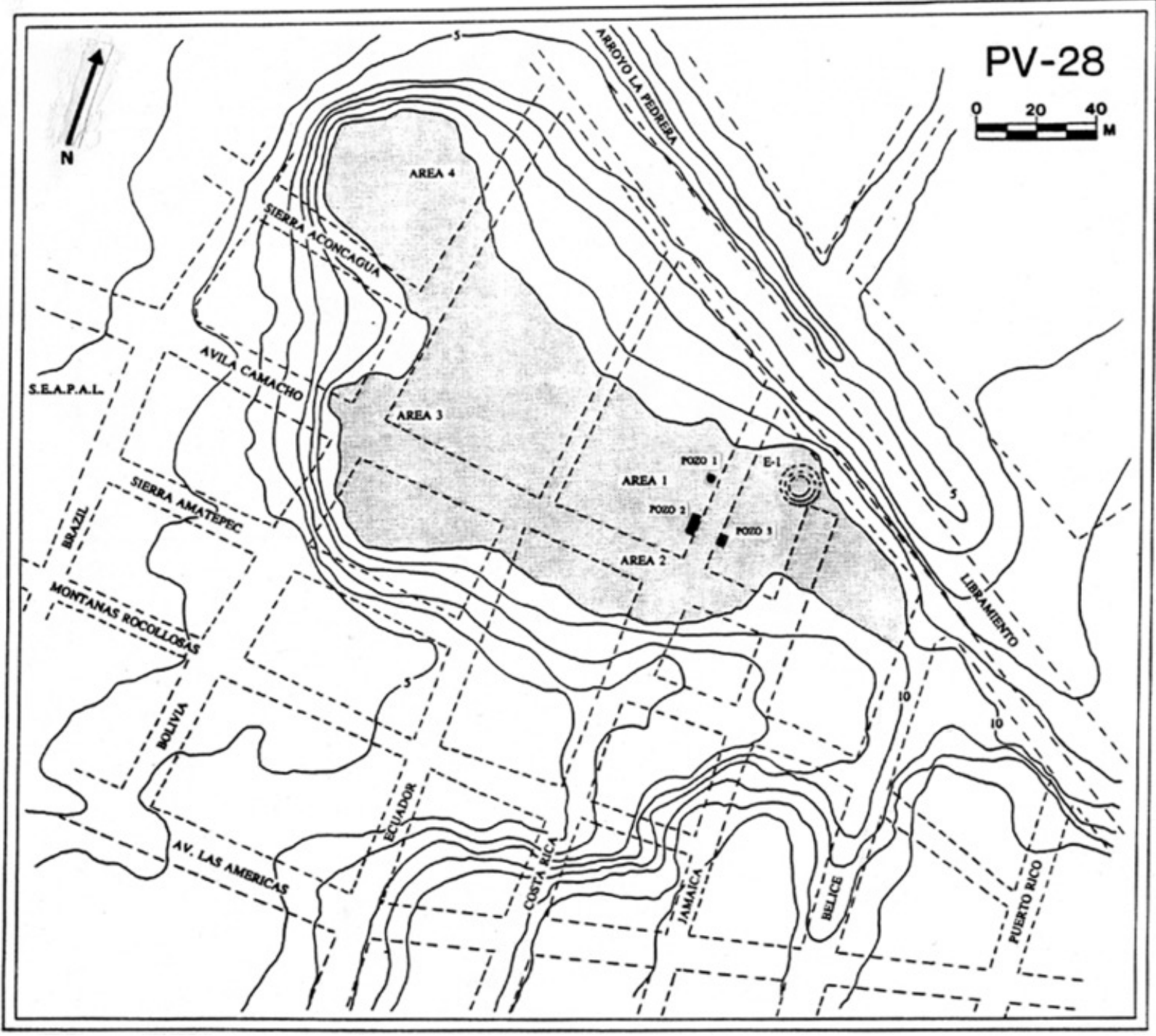

Figure 13. Map of the La Pedrera (PV-28) Site. Key: "pozo" = our excavations. 
eastern edge of Costa Rica Street he discovered a large hollow pottery figurine of the type commonly found in Late Formative/ Early Classic period shaft-and-chamber tombs in the State of Nayarit, to the north (Figure 14). This discovery motivated us to open excavations on both sides of the street in order to investigate the context of the figurine, as well as look for more evidence of this occupation of the site.

In the excavation that we conducted in the area where the figurine was discovered, we found a pit extending to the north of the location of the figurine. The pit could have once held the flexed remains of an adult, although it contained no traces of bone. Just to the northwest of the place where the figurine was found we discovered a large part of a cream-slipped bowl that had been ceremonially "killed" by punching a hole in the bottom. So it appears the burial consisted of a subsoil pit into the northern part of which was placed the body and in the southern end were placed offerings of a bowl and a hollow human figurine. The location of the burial appears to have been marked by placing a white stone cobble above the spot where the figurine was buried. This custom of marking the spot of a burial with a cobblestone appears to have been one of the mortuary customs of the Late Formative/Early Classic period because it is repeated not only in many other burials at La Pedrera, but also in other cemeteries, for example at El Colorado (PV-89).

On the western side of Costa Rica Street (Figure 13), our excavations uncovered an extremely simple shaft-and-chamber tomb (Table 1, 28-1). The shaft had been excavated to a depth of $70 \mathrm{~cm}$ into the subsoil, and on the western side of the shaft near the bottom we found a small red-painted jar. Behind the jar we found a small chamber of a size only adequate for having buried the body of an infant. No human remains could be detected within the chamber.

To the north of this simple shaft-and-chamber tomb burial (Figure 13) we found six places with pottery offerings, each of which was marked with a smooth white cobblestone (Figure 15). The earth associated with the offerings often seemed somewhat darker than the outlying earth, but in no case did we find human bones. It seems logical to assume that these offerings indicate places where human remains were buried but the acidity of the soil destroyed the bones.

The pottery vessels left as offerings have three types of decoration: painting of the entire exterior in red or orange paint; designs painted in red over a cream-colored slip; and triangle or diamond-shaped cross-hatched designs incised into an unpainted surface (Figure 16). The incised decoration and the red/cream decoration is similar to that found at the Pozo de Doña Amparo site, as well as to pottery of the Tuxcacuesco/Ortices tradition found in the Tomatlán Valley of Jalisco close to the Pacific Coast to the west, where it has been radiocarbon dated between 190 в.C. and A.D. 300 (Mountjoy 1989).

In one of the locations of offerings on the western side of the street we found a solid red/cream decorated figurine of a type commonly associated with shaft-and-chamber tombs in Nayarit to the north but with its head resting on a plate with incised decoration linking it to the Tuxcacuesco/Ortices tradition to the south (Figure 17). The figurine and the plate were found in association with three small squash-form jars, one plain ware and the other two painted red. Another offering, found a short distance to the north, was a whistle in the shape of a hollow dog, with creamcolored designs painted over an orange slip.

In the middle of these six locations with offerings, we found a large jar that was likely a funerary urn. Inside this urn we found a small plain ware jar and fragments of a red-on-cream decorated bowl that appears to have been inverted to serve as a cover for the mouth of the urn. As in the case of other Late Formative/Early Classic cemeteries in the municipality of Puerto Vallarta, the use of this burial urn seems to have been contemporaneous with other forms of burial, specifically shaft-and-chamber tombs and simple pit burials. As is common at other sites of this period, the burials appear to have been placed in a special location apart from the area of habitation.

\section{CONCLUSIONS}

Archaeological investigations conducted on the south side of the Banderas Valley, especially during the field seasons of 1993 and 1994, have resulted in much new information about mortuary customs of the native people who lived in this area during the Late Formative/Early Classic period. For one thing, a variety of forms of burial were apparently contemporaneous in the cemeteries of this period, one of which was burial in a shaft-and-chamber tomb.

Beyond this conclusion, with respect to shaft-and-chamber tomb burials, it has been possible to achieve the following results from our investigations: (1) verification of the presence of such tombs in the Banderas Valley; (2) understanding of some of the variables that were important in picking a location for such burials, especially a special type of subsoil derived from the decay of volcanic rhyolite, commonly outside of the area of domestic habitation; (3) documentation of variety in the forms of such tombs, in the options for sealing the entrance, and in the offerings (if present) deposited with the human remains; (4) discovery of a stone tool for digging tombs and a tomb door slab with a petroglyph on one surface; (5) dating of some tombs either directly by radiocarbon analysis or by ceramic cross-dating with radiocarbon-dated deposits at other sites, indicating that the use of shaft-and-chamber tombs in the Banderas Valley began in a local phase corresponding to the Mesoamerican Late Formative, and continued at least into a phase corresponding to the Early Classic.

It has also been possible to document several aspects of the human remains that were buried in shaft-and-chamber tombs in this area, including (1) the practice of burying human remains along with offerings in the shaft as well as the chamber; (2) the custom of cremating the bodies of the deceased, and of doing so to bodies that were in different states of decomposition when cremated, implying curing of the bodies for differing times before cremation and burial; (3) the burial of infants as well as sub-adults and adults, sometimes in the same shaft or tomb; and (4) the identification of some types of skeletal pathology in the preHispanic population responsible for using such tombs.

We do not believe the custom of depositing human remains accompanied with offerings in the shaft of shaft-and-chamber tombs has been recorded previously for such tombs. Informants told Peter Furst (1966: 61-62) that they found human burials, pottery vessels, and one figurine at the Cuatro Albillas site in southern Nayarit placed around the upper mouth of the shaft of the most elaborate tomb in the cemetery, but these remains apparently were not found within the shaft, and certainly not at the bottom of the shaft.

Likewise, although cremation of the deceased has been reported for later time periods in pre-Hispanic West Mexico (Cabrero and López 1995), the only evidence thus far for cremation of the human remains buried in shaft-and-chamber tombs comes from the El Reparito and El Pozo de Doña Amparo sites in the Banderas Valley in Jalisco, from a tomb at the El Piñón site in Zacatecas 


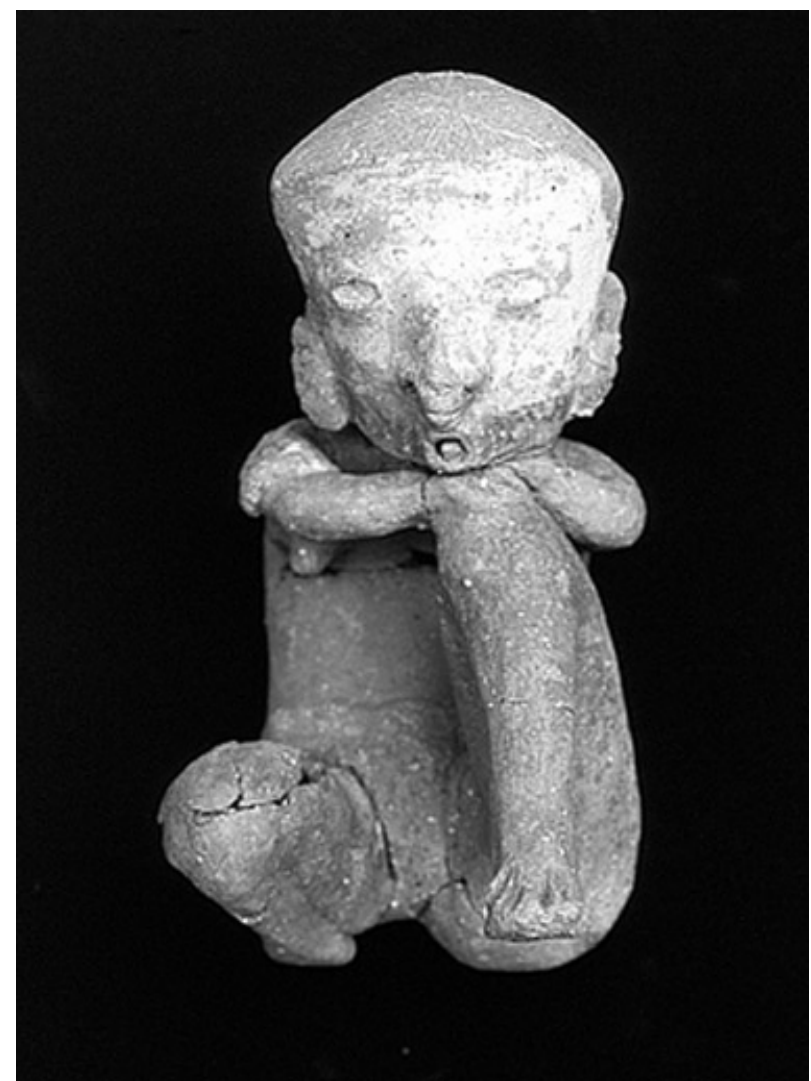

Figure 14. Large hollow figurine found in the area of excavation 3 at the La Pedrera (PV-28) site. Height $23.0 \mathrm{~cm}$.

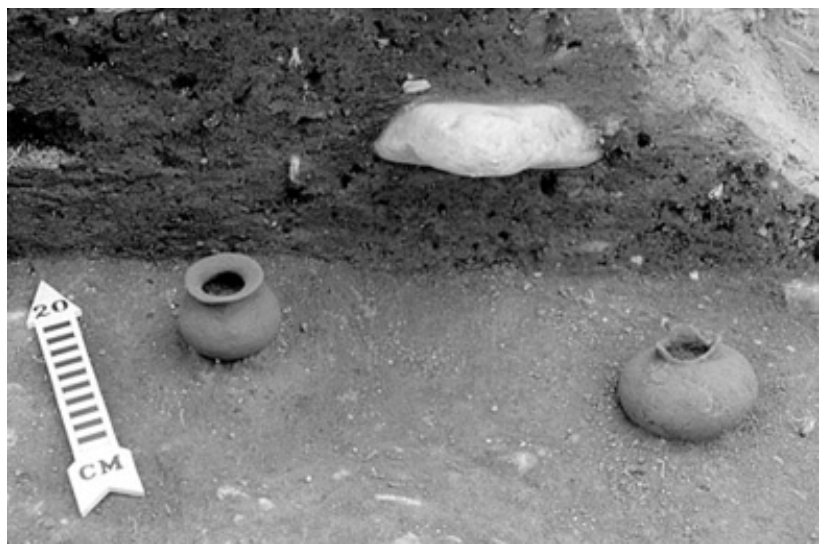

Figure 15. Pottery burial offerings in place, and the location marked by a smooth white stone, found in excavation 2 at the La Pedrera (PV-28) site.

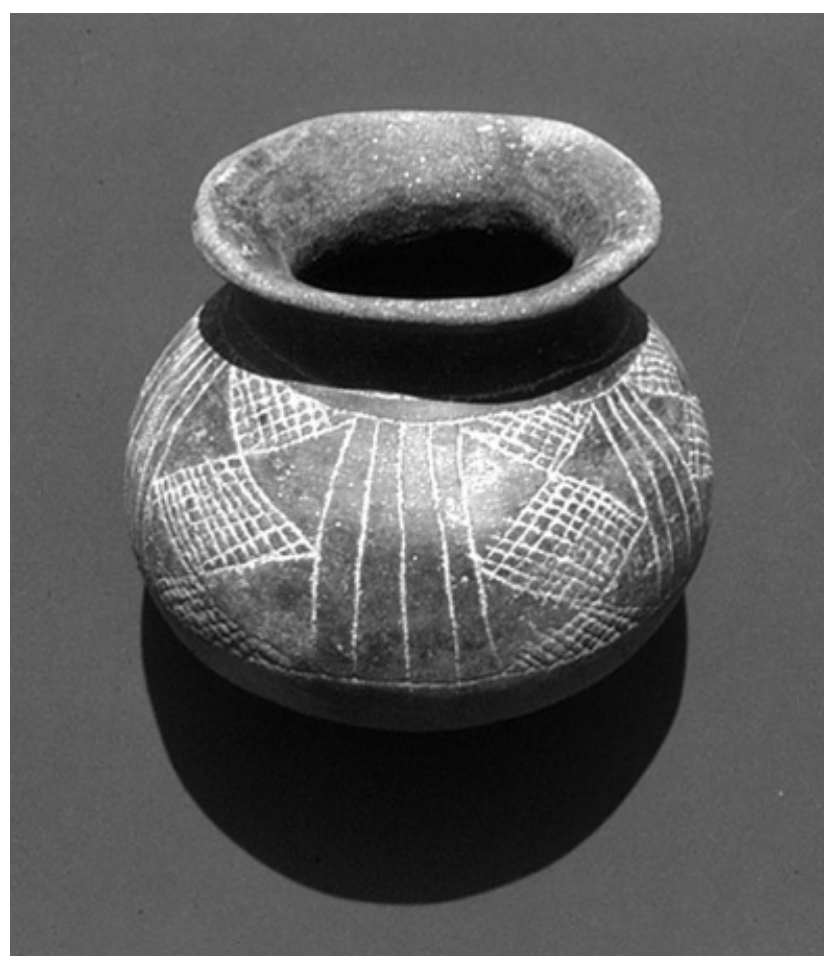

Figure 16. Tuxcacuesco Incised decorated jar found in excavation 2 at the La Pedrera (PV-28) site. Height, $10.0 \mathrm{~cm}$.

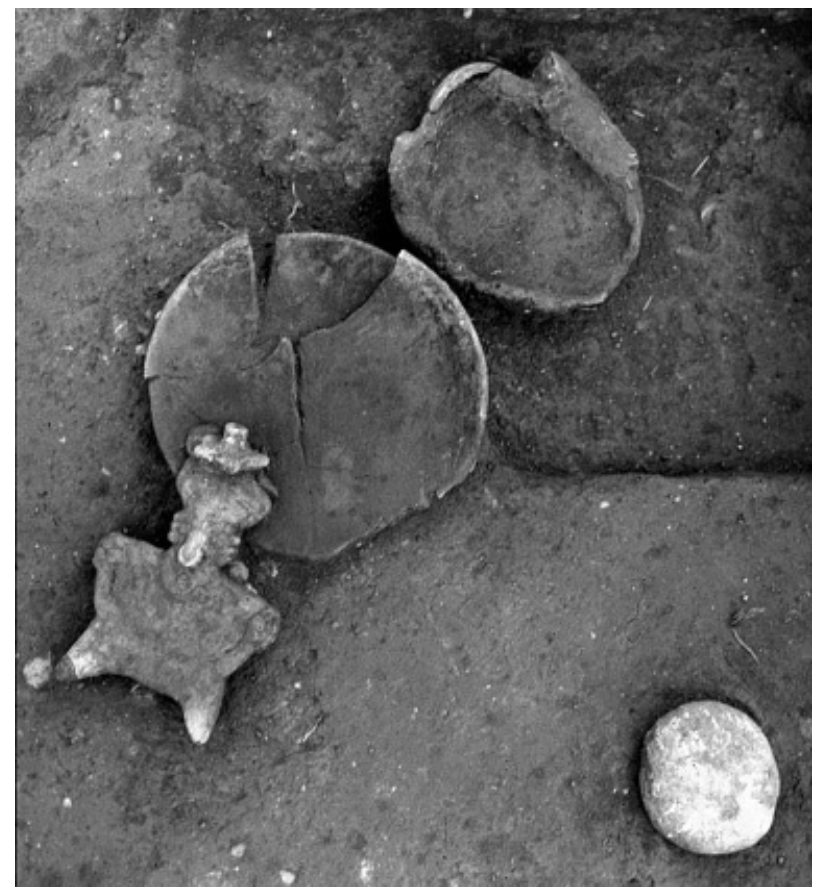

Figure 17. Solid figurine of Nayarit shaft tomb style (height $18.0 \mathrm{~cm}$ ), with its head resting on plate of Tuxcacuesco Incised pottery, diameter $19.75 \mathrm{~cm}$, a type characteristic of the central coast and southern coast and highlands of Jalisco. 
(Pickering and Cabrero 1998), and from a partially looted shaftand-chamber tomb radiocarbon dated with $95 \%$ confidence in the range of 900 to 800 B.C. (Beta-211717) that we excavated in 2005 at the Los Coamajales site in the Mascota Valley of western highland Jalisco.

In the Banderas Valley area there seems to have been at least one case of the curated of bodies for different periods before cremation. Possible curing of non-cremated human remains before burial in shaft-and-chamber tombs has been suggested for the shaft tomb burials discovered at the Huitzilapa, Jalisco, site (Pickering and Cabrero 1998). Also, curing of non-cremated bodies is the most likely explanation for the multiple interments in different states of decomposition recovered from shaft-and-pit burials we have excavated from the El Pantano cemetery (ca. 800 B.c.) in the Mascota Valley during fieldwork carried out from 2000 through 2005, as well as for some of the shaft-and-chamber burials excavated at the El Embocadero II site radiocarbon dated with $95 \%$ confidence in the range of 820 to 770 B.C. (Beta 211716) in the Mascota Valley during the 2005 field season.

We believe this evidence supports the idea of community or lineage groups having held one burial ceremony during the dry season which involved the one-time interment of the remains of deceased whose bodies had been curated awaiting the yearly burial ceremony that to some extent was a ritual of renewal that symbolically planted the deceased at the end of the dry season to fructify the population in much the same way that seeds are planted at the end of the dry season to grow sustenance for the group during the rainy season (Mountjoy 1998a). Pickering and Cabrero have suggested (1998) that such osteological evidence supports the idea of periodic reopening and reuse of some shaft-and-chamber tombs. Although this seems possible for some of the large and deep multichambered shaft-and-chamber tombs such as the one at Huitzilapa, it does not seem a viable explanation for the simpler and shallower multiple burials at the sites we have excavated in Jalisco.

Although the interment of multiple burials in shaft tomb chambers is well documented in West Mexico (Cabrero and López 1995;
López and Ramos 1998), when age estimates are available for the burials they have usually indicated skeletal remains of adults (Long 1966). The only instances of which Mountjoy is aware, outside of the Banderas Valley in Jalisco, of documenting the remains of infants and sub-adults in such tombs come from the El Moralete site in Colima and are dated to the Comala phase (A.D. 500-600) (Deraga and Fernández 1994), and in one of three tombs dated in the A.D. 135-440 range at the El Piñón site in Zacatecas (Pickering and Cabrero 1998; Cabrero and López 1998). It is worth mentioning, however, that burial of infants, sub-adults, and adults in the same tomb has been amply documented in fieldwork 20002005 at the El Pantano, Jalisco, cemetery (ca. 800 B.c.).

Osteological studies of human remains from shaft-and-chamber tombs are rare, not only because so few such tombs have been excavated by professional archaeologists but also because bone preservation is often poor, for example in the tombs excavated at Los Tabachines (Galván 1991). Furthermore, trained osteologists have not always been available to study the remains. There is, however, osteological evidence from shaft tomb burials in the Banderas Valley of Jalisco for (1) periosteal inflammation of the tibia similar to that seen in treponemal infections; (2) diffuse pitting and thickening of bone, consistent with porotic hyperostosis produced by iron deficiency anemia or treponemal infection; (3) periodontal disease; and (4) possible myositis dessicans secondary to a femoral fracture.

Lastly, the data seem to support the idea of a "soft frontier" in the Banderas Valley between somewhat different pre-Hispanic archaeological cultures in Nayarit and Jalisco during the Late Formative/Early Classic period. The support consists principally of having found cemeteries of this period which contain a contemporary mix of types of burial characteristic of the coastal zone of Nayarit to the north and the coastal zone of Jalisco to the south, as well as a mixture in the same tomb of pottery offerings characteristic of the pre-Hispanic cultural traditions that were characteristic of those two geographic areas (Mountjoy 1998b).

\section{RESUMEN}

En este artículo se reportan los resultados de nuestro intento de localizar y estudiar tumbas de tiro y bóveda en el municipio de Puerto Vallarta en el lado sur (de Jalisco) del valle de Banderas en la costa del Occidente de México, así como colocar estas tumbas en el contexto más amplio de costumbres de enterramiento que existieron durante un tiempo que corresponde al formativo tardío y el clásico temprano de Mesoamérica. Durante las temporadas de 1993 y 1994 localizamos y estudiamos nueve sitios en donde la gente local había encontrado y saqueado tumbas de tiro y bóveda, pero nos enfocamos aquí en tres sitios (El Reparito, El Pozo de Doña Amparo, y La Pedrera) en donde encontramos y excavamos tumbas de tiro y bóveda no saqueadas o parcialmente saqueadas. En el proceso de estas investigaciones obtuvimos evidencias de: (1) el lugar y el tipo de tierra selecionados para excavar tales tumbas; (2) la variación en la forma y el contenido de los tiros y las bóvedas; (3) las hierramentas para excavar y las maneras de sellar las tumbas; (4) la colocación cronológica de tales tumbas; (5) patología en la población prehispánica responsable para la excavación de tales tumbas; (6) cremación de los cuerpos y la curación de los cuerpos por diferentes períodos de tiempo hasta su incineración; y (7) la existencia de formas alternativas de enterramiento en asociación con tumbas de tiro y bóveda. Además, la información obtenida apoya la idea de que el río Ameca y el valle de Banderas fue una frontera "blanda" entre tradiciones distintivas localizadas al norte y al sur del río, en donde hasta cierto punto estas dos tradiciones se mezclaron.

\section{ACKNOWLEDGMENTS}

The research on which this article is based was supported by the Research Council of the University of North Carolina at Greensboro, the WennerGren Foundation for Anthropological Research, the Jalisco Regional Center of the Mexican National Institute of Anthropology and History, the Municipality of Puerto Vallarta, and the University of Guadalajara. The research was conducted under permits issued by the Archaeological Coun- cil of the Mexican National Institute of Anthropology and History. Preliminary versions of this paper were delivered at the II World Congress on Mummy Studies in Cartagena, Colombia and the Denver Museum of Natural History in 1995; at the Annual Meetings of the Society for American Archaeology in New Orleans in 1996; and at the Art Institute of Chicago in 1996. 
This article is dedicated to Chema Peña of Las Palmas, Jalisco, who under other circumstances in life could have become a great professional Mexican archaeologist, and from whom I have learned many things. This

\section{REFERENCES}

Cabrero G., María Teresa, and Carlos López

1995 La muerte en el Occidente del México prehispánico. Instituto de Investigaciones Antropológicas. Universidad Autónoma de México. Mexico City.

1998 Las tumbas de tiro de El Piñón, en el cañón de Bolaños, Jalisco, México. Latin American Antiquity 9:328-341.

Deraga, Daría, and Rodolfo Fernández

1994 Las tumbas de tiro de El Moralete, Colima. Barro Nuevo, edición especial: $27-30$.

Evans, Nancy H.

1971 Tourist Contact and Culture Change in the Banderas Valley, Nayarit and Jalisco, Mexico. Masters Thesis, California State College. Long Beach.

Furst, Peter T.

1966 Shaft Tombs, Shell Trumpets and Shamanism: A Culture-Historical Approach. Ph.D. Dissertation, University of California, Los Angeles.

Galván V., L. Javier

1991 Las tumbas de tiro del Valle de Atemajac, Jalisco. I.N.A.H. Colección Científica, No. 239. México, D.F.

Grosscup, Gordon L.

1976 The Ceramic Sequence at Amapa. In The Archaeology of Amapa, Nayarit, edited by C. Meighan, pp. 207-272. Monumenta Arqueologica 2. The Institute of Archaeology, University of California, Los Angeles.

Kan, Michael, Clement Meighan, and Henry Nicholson

1989 Sculpture of Ancient West Mexico: Nayarit, Jalisco, Colima. Los Angeles County Museum of Art and the University of New Mexico Press. Albuquerque.

Kelly, Isabel T.

1949 The Archaeology of the Autlán-Tuxcacuesco Area of Jalsico: II: The Tuxcacuesco-Zapotitlán Zone. Ibero-Americana, No. 27. University of California Press. Berkeley.

Long, Stanley V.

1966 Archaeology of the Municipio of Etzatlán, Jalisco. Ph.D. Dissertation, University of California, Los Angeles.

López M. C., Lorenza, and Jorge Ramos de la Vega

1998 Excavating the Tomb at Huitzilapa. In Ancient West Mexico: Art and Archaeology of the Unknown Past, edited by Richard Townsend, pp. 53-70. The Art Institute of Chicago, and Thames and Hudson.

Meighan, Clement W.

1972 Archaeology of the Morret Site, Colima. Publications in Anthropology, No. 7. University of California Press.

Mountjoy, Joseph B.

1982 El Proyecto Tomatlán de salvamento arqueológico. Colección Científica Arqueología, no. 122. Instituto Nacional de Antropología e Historia, Mexico City.

1989 Algunas observaciones sobre el desarrollo del preclásico en la llanura costera del Occidente. In El preclásico o formativo: avances y study would not have been possible without Chema's having shared his considerable knowledge and having assisted me in the field seasons of 1993 and 1994. perspectivas, edited by Martha Carmona M., pp. 11-26. Instituto Nacional de Antropología e Historia, Museo Nacional de Antropología. Mexico City.

1992 Rescate arqueológico en el sitio de La Pedrera. Report, 17 pp., to the Instituto Nacional de Antropología e Historia, Departamento de Arqueología. Mexico City.

1993 El pasado prehispánico del municipio de Puerto Vallarta. In Una aproximación a Puerto Vallarta, edited by J. Olveda, pp. 23-40. The Colegio de Jalisco, the H. Ayuntamiento Constitucional de Puerto Vallarta, and the Fundación Cambio XXI. Zapópan, Jalisco.

1998a The Evolution of Complex Societies in West Mexico: A Comparative Perspective. In Ancient West Mexico: Art and Archaeology of the Unknown Past, edited by Richard Townsend, pp. 251-265. The Art Institute of Chicago, and Thames and Hudson.

1998b El valle de Banderas como zona fronteriza durante el preclásico tardío. In El occidente de México: arqueología, historia y medio ambiente, pp. 255-263. Universidad de Guadalajara, and Instituto Francés de Investigación Científica para el Desarrollo en Cooperación. Guadalajara, Jalisco.

2000 Prehispanic Cultural Developments along the Southern Coast of Western Mexico. In Greater Mesoamerica, edited by Michael S. Foster and Shirley Gorenstein, pp. 81-106. University of Utah Press, Salt Lake City.

2004 El desarrollo de cultura prehispánica en la costa de Jalisco, municipio de Puerto Vallarta. In Introducción a la arqueología del Occidente de México, edited by Beatriz Braniff C., pp. 339-369. Mexican Nacional Institute of Anthropology and History and the University of Colima. Colima.

Mountjoy, Joseph B., Tammy Smith, Ryun Papson, Deborah Guida, John Pleasants, Chris Witmore, and Cheryl Cross

2003 Arqueología del municipio de Puerto Vallarta. www.uncg.edu/ arc/Vallarta and distributed in CD Rom form by the University of Pittsburg Press.

Pickering, Robert B., and María Teresa Cabrero

1998 Mortuary Practices in the Shaft-Tomb Region. Ancient West Mexico: Art and Archaeology of the Unknown Past, edited by Richard Townsend, pp. 71-87. The Art Institute of Chicago, and Thames and Hudson.

Sandford, Mary K., Georgeanne Bogdan, David Weaver, Grace Kissling, and Mary Powell

2005 Prehistoric treponematosis at the Tutu site. In The Myth of Syphilis: The Natural History of Treponematosis in North America, edited by Mary L. Powell and D. C. Cook, pp. 402-417. University of Florida Press, Gainesville.

Ubelaker, Douglas L.

1989 Human Skeletal Remains: Excavation, Analysis, and Interpretation, 2nd edition. Taraxacum Press. Washington, DC. 
Reproduced with permission of the copyright owner. Further reproduction prohibited without permission. 